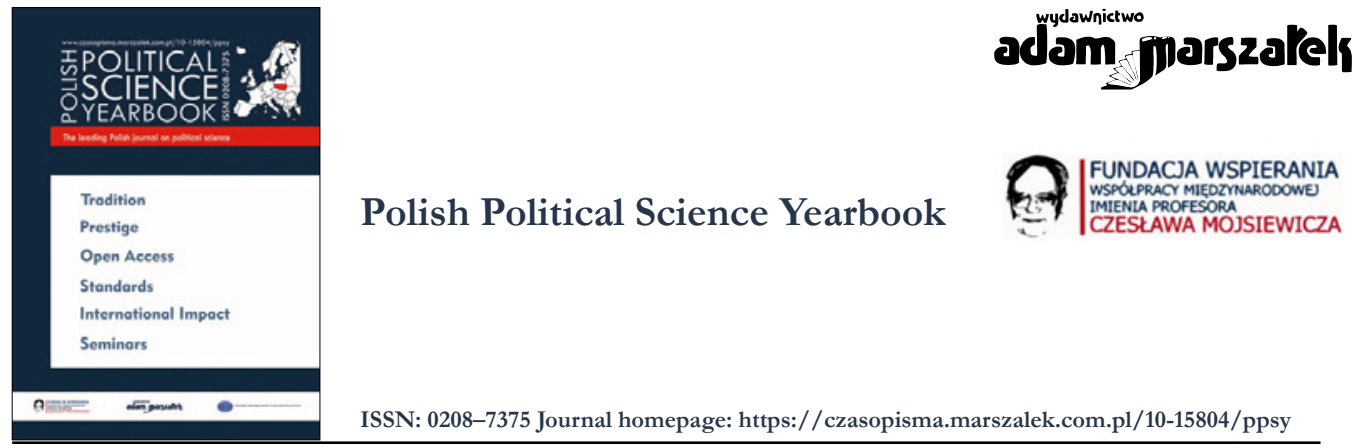

\title{
Joe Biden's Strategy in the Asia-Pacific Region: Change or Continuity. A Comparative Analysis
}

\section{Marcin Grabowski}

ORCID: 0000-0003-1447-1818

To cite this article please include the following information:

- Journal title: Polish Political Science Yearbook

- Volume number: 50

- Year of publication: 2021

- Published ahead-of-print

Example styles:

[APA Style]: Grabowski, M. (2021). Joe Biden's Strategy in the Asia-Pacific Region: Change or Continuity. A Comparative Analysis. Polish Political Science Yearbook, 50 (issue number), pages. https://doi.org/10.15804/ppsy202152

[Chicago Style]: Marcin Grabowski, “Joe Biden's Strategy in the Asia-Pacific Region: Change or Continuity. A Comparative Analysis" Polish Political Science Yearbook 50, no. [issue number] (2021).

To link to this article: https://doi.org/10.15804/ppsy202152

Published ahead-of-print

Final submission: 12 October 2021

Published online: 2 November 2021

Printed issue: 2021

Submit your article to PPSY 


\title{
Marcin Grabowski
}

Jagiellonian University (Poland)

ORCID: 0000-0003-1447-1818

e-mail: marcin.grabowski@uj.edu.pl

\section{Joe Biden's Strategy in the Asia-Pacific Region: Change or Continuity. A Comparative Analysis}

\begin{abstract}
The election of Joseph Biden for the office of the President of the United States has brought expectations of fundamental change in American foreign policy, including policy toward the Asia-Pacific/Indo-Pacific region. As observed in the last few months, the reality has been more complex as definite changes in the US Indo-Pacific policy are not as visible as expected. It is especially in respect of the US policy toward China being more a continuation than a change from Donald Trump's approach. Changes are rhetorical rather than actual policies. The situation is different in the case of alliances, as Joe Biden offers much more commitment to allies like Japan or South Korea. Also, multilateral dimensions (both regional and global) witness some - however still limited - change. The main goal is to make a comparative analysis of Joe Biden's policy toward Asia, referring to the administrations of Barack Obama and Donald Trump. Hence the strategies of pivot/re-balance toward the Asia of Obama, and the free and open Indo-Pacific strategy of Trump, will be examined. The analysis refers to the complex interdependence theory and the power transition theory. Methodologically, it is based on document analysis with comparative analysis.
\end{abstract}

Keywords: Joe Biden, Asia-Pacific, Indo-Pacific, United States, Barack Obama, Donald Trump

\section{Introduction}

The Asia-Pacific/Indo-Pacific ${ }^{1}$ region has been gaining progressively more importance in American foreign policy, as it has been developing into a global center of gravity for political and economic reasons. Additionally, Asia is home to the biggest possible competitors,

1 Asia-Pacific name had been predominately used through Barack Obama administration, whereas Donald Trump introduced Indo-Pacific term into American strategic documents, therefore both terms are used in the comparative analysis within this article. 
challenging US global and regional dominance, with China being the principal competitor. Consequently, the region has become the most important subject of American foreign policy, playing a crucial role in its strategies. This process started after the end of the Cold War, accelerating within the last decade. There were two prominent strategies: Barack Obama's pivot/re-balance to Asia strategy and Donald Trump's free and open Indo-Pacific strategy. The new American president, Joe Biden, may build on one of those strategies or alter them entirely. The election of Joe Biden to the President of the United States has brought an expectation of fundamental change in American foreign policy, including the policy toward the Asia-Pacific/Indo-Pacific regions. As observed in recent months, the reality has been more complex, as tangible changes in the US Asia-Pacific policy are not as visible as expected. It is especially connected with the US policy toward China being more a continuation than a change to Donald Trump's approach. Changes appear in rhetoric rather than actual policy. The situation is different in the case of alliances, as Joe Biden presents more commitment to allies, such as Japan or South Korea. Multilateral dimensions - both regional and global - witnessed some change, although still limited.

The main goal is to make a comparative analysis of Joe Biden's policy toward Asia, referring to the administrations of Barack Obama and Donald Trump. The analysis considers the goals of American foreign policy, determined by the set of factors that built the relative power of the United States globally and in the Asia-Pacific region. It accounts for the different strategies of maintaining the dominant position at the time of a relative power decline of the United States. Those strategies correlate with two theoretical traditions located within the liberal paradigm: complex interdependence and power-transition theory within the realist paradigm. These theories properly illustrate two basic dimensions of Sino-American relations, competition for primacy in the international system on the one hand and complex relations - especially in the economic sphere - strengthening the bilateral cooperation on the other. They also exemplify the different approaches of Barack Obama and Donald Trump toward the relative decline of the United States and the relative rise of the People's Republic of China. Complex interdependence is associated with the theory introduced by Joseph Nye and Robert Keohane. We may presume that due to the complex economic interdependence between the United States and China, exemplified by two dimensions - sensitivity and vulnerability - the level of rivalry between them is limited. Consequently, the US would rather search for tools to maintain its dominant position by strengthening different components of power. The power transition theory is based on Abramo Organski and Jacek Kugler's works, according to which a major war and a new multipolar or unipolar system may emerge in case of the challenger's rising power at the power maturity stage. Therefore, as China is gradually reaching this power maturity stage and is a crucial US competitor, the American administration may seek to weaken the People's Republic of China (PRC) ${ }^{2}$. Having that in mind, two main hypotheses drive this paper:

\footnotetext{
2 The analysis of selected elements of Sino-American relations on the basis of both complex inter-
} 
H1: American strategy toward the Asia-Pacific region results from its interests (including a relative decline of power); hence its goals remain similar despite changing administrations.

H2: Joe Biden's policy in the Asia-Pacific region will continue Donald Trump's policy with changes mostly regarding tools, not necessarily goals.

The hypotheses imply an application of the theories, with the application of the liberal paradigm (exemplified by the complex interdependence theory) and the realist paradigm (exemplified by the power transition theory). Hence those theories are a basis for the analysis. Obama's administration is associated with a liberal paradigm, whereas Trump's administration is associated with a realist one. Inspecting Joe Biden's administration, both paradigms are tested. Methods of data collection applied in the article include document analysis (focusing on American strategic documents published by the White House, Department of State, Department of Defense), and quantitative data (for descriptive statistics) of the International Monetary Fund, International Bank of Reconstruction and Development and the Asian Development Bank. In terms of data analysis: for the power assessment, Enrico Fels' model of the composite index of aggregate power is used, as well as comparative analysis and historical analysis to compare US administrations' policies toward the Asia-Pacific region ${ }^{3}$.

\section{Sino-American Power Competition}

The competition for leadership in the global and regional (Asia-Pacific) system has been a dominant analytical factor in international relations and a crucial determinant for policymakers in the United States. Therefore, an assessment of factors that define the power of the leader and challenger in the system seems crucial. As basic determinants of power remain the same and indicate the relative power decline of the United States at the time of China's rise, we may presume that the basic goals of American administrations remain the same, that is that the US aims at maintaining leadership in the Asia-Pacific region and the world. At the same time, different administrations use different tools for this goal. One may simplify the problem by stating that Barack Obama tried to maintain the US position by setting norms and rules and building institutions reinforcing America's position. In contrast, Donald Trump aimed to weaken the main competitor (China) by the trade and technology war. Somewhat surprisingly, if looking at the policies of Joe Biden, we could presume that

dependence theory and power transition theory in this article is partially based on texts by Duggan and Grabowski (Duggan \& Grabowski, The Influence of Covid-19..., 2021 and Grabowski \& Duggan, Donald Trump Presidency..., 2021).

3 The main theoretical settings for the current analysis are adapted partially, from Grabowski \& Pugacewicz, 2019. 
he may combine both approaches, focusing on an institutional setting and support of alliances, but not necessarily abandoning anti-Chinese measures.

An assessment of the relative distribution of power, as well as the power of individual states, is challenging and controversial. However, we may apply the formula of Enrico Fels, an adaptation of Ray Cline's formula (arbitrary elements were not included in the modified formula). Consequently, Enrico Fels kept three categories of critical mass, economic and military capability, and quantified it based on fifty-five variables, including forty-four Asia-Pacific countries (the analysis of Cline's formula and methodology of Composite Index of National Power (Fels, 2017)). As a result of the analysis (actually, I refer to CIAP I, with weight 1 for critical mass, 2 for economic power, and 2 for military power. This version of the Composite Index of Aggregate Power is more favorable for the United States; Fels concluded that the United States had been a dominant power throughout this period (1992-2012), but that its comparative advantage had decreased in relation to all the main regional powers (apart from Japan). This decline has been evident regarding China, whose power in 2012 was equivalent to 89.4\% of America's power, compared to 34.7\% of America's power in 1992 (Fels et al., 2017). From this, we may associate the pivot/re-balance with the relative rise of Chinese aggregated power.

Bearing in mind the relative distribution of power in the Asia-Pacific region becoming more favorable for the United States, Barack Obama focused more on other determinants of power, including middle power allegiance (Australia, Pakistan, Japan, Republic of Korea, Thailand, and Indonesia). Out of this group, only Pakistan has been shifting its loyalty toward the PRC in the twenty-first century. Other middle powers of the region collaborate more closely with the United States (Fels et al., 2017). This strategy became more complicated during the presidency of Donald Trump, as on the one hand, he developed the concept of QUAD (Quadrilateral Security Dialog), the quadrilateral security dialogue between the United States, Australia, Japan, and India (connected with the Indo-Pacific strategy), as well as other regional, predominately bilateral alliances. On the other hand, he introduced a transactional approach to alliance relations, causing rising distrust among US allies in the region. However, Joe Biden is perceived as focusing more on building positive relations with regional alliances.

The next dimension, supporting the American position in the region, is associated with regional institutions, including the International Monetary Fund, with $16.51 \%$ of votes (IMF, 2020) guaranteeing the de facto right of veto in the most important issues, as well as the World Bank, including the IBRD with 15.44\% (International Bank for Reconstruction and Development, 2020). As for Asia-Pacific or Indo-Pacific institutions, the Asian Development Bank seems crucial (the US holds $15.6 \%$ of its shares, as does Japan) (Asian Development Bank, 2020), allowing the US to maintain economic influence in the region. Other regional institutions include the Asia-Pacific Economic Cooperation (APEC), despite the decline of America's role since the 1997 Asian Financial Crisis. That is why the idea of the TransPacific Partnership allowed the US to act as the setter of norms and rules in the region 
(hence maintaining a higher position in the region than those simply stemming from the relative distribution of power). Unfortunately, Donald Trump decided to withdraw the US from this agreement, limiting this strategic advantage of the United States (Grabowski \& Pugacewicz, 2017).

Having those dimensions in mind, Joe Biden's strategy should and may address different dimensions of American power; while strengthening the aggregate power of the US is important, developing a proper network of international institutions, norms and rules seems crucial. Therefore, Biden's policy may be explained both in realist terms (with a focus on power and power transition) and liberal ones (focusing on complex interdependencies in the region).

\section{Barack Obama Pivot to Asia}

The policy of Barack Obama's administration is usually associated with the concept of the pivot, later renamed re-balance, to Asia with the military dimension attracting the attention of analysts and politicians. There were three basic dimensions of the pivot: diplomatic (bilateral and multilateral diplomacy), military, and institutional. Specifically, building a new institutional architecture in the region based on the Trans-Pacific Partnership (TPP) (a broad and multidimensional analysis of this concept and policy was presented by its crucial architect, Kurt Campbell, analyzing the idea of the pivot to Asia, responding to the criticism toward this idea, describing changes in the regional system, American strategy toward the region in its historical and contemporary dimensions, as well as particular elements of the strategy itself, risks embedded, and the implementation of the strategy (Campbell, 2016)). The military component, often referred to by analysts, included the deployment of marines in Darwin, Australia, use of Singapore by the American navy, and military cooperation with the Philippines, but in fact, does not seem to be crucial. Two other components should be stressed more, namely strengthening multilateral cooperation and creating a new institutional setting in the region. The latter appears the most important in the pivot. As for multilateral cooperation, joining the East Asia Summit in November 2011 was a symbolic move. Regarding the new economic architecture, negotiations on the Trans-Pacific Partnership (TPP) (see more on TPP: Grabowski, 2011), being the high-quality free trade area (Manyin et al., 2012), were crucial for the United States. The Trans-Pacific Partnership could allow the United States to attain the position as the setter of norms and rules, allowing it to have a higher position than it would have had from its decreasing relative position in the power distribution of the Asia-Pacific region. The final text of the agreement was approved in October 2015 and signed in February 2016. It was not ratified by the United States, as Donald Trump decided to withdraw from the agreement in January 2017. It resulted in a new phase of negotiations led by Japan, resulting in a new agreement between eleven parties known as the Comprehensive Progressive Trans-Pacific Partnership, signed in March 2018 (Elms, 2018). 
The re-balance/pivot to Asia was communicated in the US National Security Strategy of 2015, with a sub-chapter of the document devoted to the problem and entitled Advance Our Rebalance to Asia and the Pacific, with a stress on the fact that The United States has been and will remain a Pacific power. Further, a justification and goals of the policy included the rising role of Asia in the global, especially economic, system; security dynamics, especially maritime security (South-China Sea) and a provoking North Korea; modernization of alliances with Japan, South Korea, the Philippines, and Thailand, with a stress on a return to democracy in the latter; support for regional institutions - Association of Southeast Asian Nations (ASEAN), East Asia Summit (EAS), Asia-Pacific Economic Cooperation (APEC), Trans-Pacific Partnership (TPP) - with America's central role stressed in the document; partnership with Vietnam, Indonesia, and Malaysia; support for reforms in Myanmar; strategic partnership with India - the convergence between the Indian' Act East' Policy and American re-balance to Asia; cooperation with India and Pakistan to counter terrorist threats (The White House, 2015; Marszałek-Kawa \& Dmochowski, 2021).

This strategic document illustrated American priorities and the most important areas of cooperation in different dimensions, including bilateral and multilateral, as well as military, economic, and institutional settings of the policy. The policy of Barack Obama, despite bold goals and a standard approach, concerning the declining strategic advantage of the US, had severe problems with the implementation due to lack of support in Congress and the withdrawal of his successor from some crucial initiatives (including the Trans-Pacific Partnership).

\section{Donald Trump and the Indo-Pacific Region}

The policy implemented in the region by Donald Trump's administration is usually associated with the Indo-Pacific term. This term was implemented into the National Security Strategy of the US (published in November 2017). The region was defined as spreading from the western coast of India to the western coast of the United States, with the stress on being the most populous and most dynamic region in the world. The key element in this document was a statement on the Free and Open Indo-Pacific region. The most important challenges in the region included the question of China (an expression of a will to cooperate, with restrictions caused by the use of economic and military tools to reach Chinese geopolitical goals, especially in the South-China Sea), North Korean cybersecurity issues, as well as missile and nuclear programs. As for the alliance structure, commitments were confirmed regarding Japan, South Korea, Australia, and New Zealand, focusing on the new strategicmilitary component of the Indo-Pacific concept. It included the QUAD between the United States, Japan, India, and Australia. In southeast Asia, the traditional allies (Thailand and the Philippines) were mentioned, and countries of rising importance, like Vietnam, Indonesia, Malaysia, and Singapore, followed by confirmation of commitments to Taiwan and support for a strong partnership with India. ASEAN and APEC were mentioned as institutions promoting freedom-based regional order (The White House, 2017). 
In terms of strategic documents, challenges were similar to those of Barack Obama's administration. The most important doctrine connected to the region was the Vision of Free and Open Indo-Pacific, based on Donald Trump's declaration from the 2017 APEC summit in Vietnam. That vision included respect for sovereignty and independence, peaceful conflict resolution, free, fair, and reciprocal trade. The latter should be based on open investment, transparent agreements, links, and adjustment to international norms and rules, including freedom of navigation and flights (The White House, 2017).

Those general declarations were accompanied by two important reports published in 2019 by the Department of Defense and the Department of State. The former, entitled IndoPacific Strategy Report: Preparedness, Partnerships, and Promoting a Networked Region, focused on the fact that the Indo-Pacific region is a key operational theater for the United States as a Pacific nation. A strong statement in the report stressed that the Vision of a Free and Open Indo-Pacific particularly clashes with the aspirations of the PRC, using military modernization, impact operations, and a predatory economy to rearrange rules in the region. The United States stressed that it would not accept actions that would undermine order based on norms and values. Therefore, the strategy stressed a necessity for readiness (hence, to force operations and contain possible conflicts), partnerships (about existing alliances, but also new agreements), and the promotion of regional networks (such as regional security architecture) (the Department of Defense, 2019). The latter, prepared by the Department of State and entitled: A Free and Open Indo-Pacific: Advancing a Shared Vision, addressed economic aspects of regional relations, indicating USD 1.9 trillion of bilateral trade and multilevel policy conduct, with the engagement of government agencies, the business community, and other institutions. A free and open Indo-Pacific role was stressed here, with a strong focus on sub-regions and regional institutions (ASEAN, Mekong Basin countries, Pacific Islands) (Department of State, 2019).

While analyzing the policy of Donald Trump in the context of American interests, regional dynamics, and changing distribution of power in the Asia-Pacific, we may conclude that it was controversial and even counterproductive, bearing in mind the current position of the US in the region (measured by the relative distribution of power). We also consider possible options to maintain America's role in the region, being in the range of the US government (especially considering the possibility of shaping norms and rules in the region and multilateral institutions).

\section{The Agenda of Joe Biden}

When Joe Biden was elected the forty-sixth president of the United States, he brought expectations for change in the US domestic and foreign policy, including the policy in the Asia-Pacific region (the State of Southeast Asia Report 2021 indicated that $63.1 \%$ of opinion leaders in ASEAN countries expected the US, not Chinese, engagement in the region (in 2020 it was 52.7\%) (Seah et al., 2021). At the same time, changes have not been as fundamental 
as expected, especially in the US policy toward China. It would include the most important element of Donald Trump's policy, the trade war with China, as Joe Biden has kept most of the tariffs imposed by his predecessor.

Joe Biden has already experienced a set of challenges, as indicated by the group of scholars gathered by the Institute of South Asian Studies of the National University of Singapore and the Sasakawa Peace Foundation. They referred to problems caused by the trade war with China and challenges connected with his transactionalism. Apart from the Trump legacy, Biden has to face a divided American political scene, an assertive China, fears of US allies being torn between China and the United States, and smaller countries in the region experiencing even more risk connected to Sino-American competition and conflict, risking confrontation with China or abandonment by the United States (Joshi \& Atmakuri, 2021; Marszałek-Kawa \& Stelmach, 2021; Marszałek-Kawa \& Chałubińska-Jentkiewicz, 2021).

Looking at the Interim National Security Strategic Guidance, one notices that there should not be as many changes to US policy toward China. The document stresses Chinese assertiveness and that the PRC is a competitor, which may challenge the stable and open international system due to its economic, diplomatic, military, and technological power. The US strategy focused on prevailing in strategic competition with China, as its leaders acted aggressively and coercively to undermine the open and stable international system. Joe Biden has declared that it has not excluded cooperation with China (based on American national interest), but at the same time has declared support for China's neighbors, as well as to communities facing difficulties, such as Uighurs in Xinjiang, the people of Hong Kong and Tibet and closer cooperation with Taiwan (The White House, 2021). Such an assertive and multidimensional approach, focusing on diplomatic, military, and economic actions aiming at curtailing China in Southeast Asia, is visible in the RAND report and portrayed as key for long-lasting benefits for the US and Southeast Asian region itself (Geaney, 2021).

The notion of continuity rather than change, especially in US policy toward China, has been prevalent in analyses published in 2021, stressing that strategic Sino-American competition is the most important determining factor in bilateral relations. Some changes were visible in the area of climate, as both parties declared cooperation in this respect (Glaser \& Price, 2021,pp. 29-42). Continuity has also been visible in the Indo-Pacific strategy of the United States, including the Free and Open Indo-Pacific, convergent with Japanese Prime Minister Shinzo Abe's Free and Open Indo-Pacific Strategy of 2017 (Ministry of Foreign Affairs of Japan, 2017). In this context, relations with South Asia should also be maintained or even elevated to a higher level, as cooperation within QUAD may be a tool for competition with China (Mohan \& Vater, 2021). Hitherto, developments of Joe Biden's policy toward the region have confirmed this kind of two-dimensional policy. In 2021, we observed a new alliance called AUKUS (Australia, the United Kingdom, the United States) being a challenge to China and the European Union (The White House, 2021). At the same time, restraint in certain aspects of bilateral tensions was exemplified by the release of Meng Wanzhou in September 2021. The chief financial officer of Huawei was detained by Canadian authorities 
at the request of the US in 2018 and symbolized a technological war between the US and China (Palmer, 2021).

Having that in mind, we may presume that Joe Biden's Asia policy may be located somewhere in between Barack Obama and Donald Trump, even though such a conclusion seems surprising. However, it is justified bearing in mind the US interests, as well as developments and decisions of Biden's administration.

\section{Conclusions}

This article aimed to analyze the foreign policy of the US administrations toward the AsiaPacific region, focusing on predictions about Joe Biden's administration and using a comparative perspective of the two preceding presidents, namely Barack Obama and Donald Trump. Despite popular expectations for change in American policy in the Asia-Pacific region, including policy toward China, it has been insignificantly different from Biden's predecessor. The reason for this may be associated with the basic goal of American policy, namely the maintenance of strategic advantage in the Asia-Pacific region (and in the world). It should be associated with the declining relative power of the United States.

The analysis referred to the aggregate power of the United States that had significantly deteriorated in comparison to the aggregate power of China. Hence, other dimensions of power have been taken into account, including alliance relations with regional actors (especially middle powers) and institutional arrangements, strengthening norms and rules, hence the American position in spite of the relative decline of power. Formal institutionalization of the region may be an even stronger guarantee of the US position in the Asia-Pacific region.

As for the hypotheses set, we confirm the first, stating that American interests, corresponding with the relative decline of US power, define goals in the regional policy of the United States. Similarly, different administrations apply different tools to reach similar goals, with Donald Trump focusing on weakening China by the trade war and Barack Obama focusing more on diplomatic tools and institutional arrangements connecting the countries in the region and allowing the US to maintain a dominant position in the region. Those tools may be associated with two theoretical paradigms - Donald Trump's policy may be analyzed via the prism of the realist paradigm (especially the power-transition theory), wherein Trump was trying to slow down the power maturity stage of China, using mostly realist tools, but even in his case complex economic interdependence between China and the US mattered. The liberal paradigm, with a stronger role of diplomacy and multilateral institutions, dominated Barack Obama's approach, but also, in this case, both theoretical settings mattered.

Looking at Joe Biden's administration, we may assume that, despite initial expectations, his policy toward the region has not changed significantly. Reasons for such developments are fairly simple: the relative decline of American power and the similarity of goals that determine the application of a combination of the realist and liberal tools. The most signifi- 
cant changes have been visible in US relations with its allies, as they have become closer and less transactional. At the same time, we observe further strengthening of alliance policies in South Asia, military developments (like QUAD), and better relations with southeast Asian countries. Despite strong expectations, the multilateral initiatives of Joe Biden have not yet been seriously visible in the Asia-Pacific region. At the same time, an intensely competitive policy with China has been continued. Therefore, we may conclude that a mixture of liberal and realist tools will characterize Joe Biden's policy in the Asia-Pacific region.

\section{References:}

Asian Development Bank. (2021). Shareholders.https://www.adb.org/site/investors/credit-fundamentals/ shareholders

Campbell, K. (2016). The Pivot: The Future of American Statecraft in Asia. Twelve.

Department of State. (2019). A Free and Open Indo-Pacific: Advancing a Shared Vision. https://www. state.gov/a-free-and-open-indo-pacific-advancing-a-shared-vision/

Duggan, N., \& Grabowski, M. (2021). The Influence of Covid-19 on the Power Transition between the United States and China: The Case of Southeast Asia. Irish Studies in International Affairs, 32(1).

Elms, D. (2018). The Comprehensive and Progressive Trans-Pacific Partnership: Policy Innovations and Impacts. GED Working Paper. http://aei.pitt.edu/102526/1/MT_Comprehensive_and_Progressive_Trans-Pacific_Partnership.pdf

Fels, E. (2017). Shifting Power in the Asia-Pacific?: The Rise of China, Sino-US Competition and Regional Middle Power Allegiance. Springer.

Geaney, D. (2021). How the Biden Administration Should Counter China in Southeast Asia. Journal of Indo-Pacific Affairs. https://www.airuniversity.af.edu/JIPA/Display/Article/2479121/how-the-bidenadministration-should-counter-china-in-southeast-asia/

Glaser, B., \& Price, H. (2021). Continuity Prevails in Biden's First 100 Days. Comparative Connections, 23(1). http://cc.pacforum.org/wp-content/uploads/2021/05/May-2021-Comparative-Connections-23-1-2.pdf

Grabowski, M. (2011). Will Trans-Pacific Strategic Partnership Agreement increase the competitiveness of the Asia-Pacific Region? In B. Skulska, \& A. Jankowiak (Eds.), Faces of Competitiveness in Asia Pacific (pp. 61-73). Wroclaw University of Economics.

Grabowski, M., \& Duggan, N. (2021). Donald Trump Presidency and the Transformation of Sino-American Relations: Does Asymmetric Economic Interdependence Matter? Journal of Contemporary Eastern Asia, 20(2).

Grabowski, M., \& Pugacewicz, T. (2017). Is Trans-Pacific Partnership a Challenge for Transatlantic Relations?: A Comparative Analysis of TPP and TTIP in the Context of the US Global Role. In M. Zachara (Ed.) Poland in Transatlantic Relations after 1989: Miracle Fair (pp. 86-124). Cambridge Scholars Publishing.

Grabowski, M., \& Pugacewicz, T. (2019). Western IR Theories: Analytical Patterns. In M. Grabowski, \& T. Pugacewicz (Eds.), Application of International Relations Theories in Asia and Africa (pp. 61-94). Peter Lang Verlag.

International Bank for Reconstruction and Development. (2021). Subscriptions and Voting Power of Member Countries. http://pubdocs.worldbank.org/en/795101541106471736/IBRDCountryVotingTable.pdf 
International Monetary Fund. (2021). IMF Members' Quotas and Voting Power, and IMF Board of Governors. https://www.imf.org/external/np/sec/memdir/members.aspx

Joshi, Y., \& Atmakuri, A. (2021). Biden's Indo-Pacific Strategy: Expectations and Challenges. Sasakawa Peace Foundation. https://www.isas.nus.edu.sg/papers/bidens-indo-pacific-strategy-expectationsand-challenges/

Manyin, M., Daggett, S., Dolven, B., Lawrence, S., Martin, M., O’Rourke, R., \& Vaughn, B. (2012). Pivot to the Pacific? The Obama Administration's "Rebalancing” Toward Asia. CRS Report for Congress.

Marszałek-Kawa, J., \& Chałubińska-Jentkiewicz, K. (Eds.) (2021). Stosunki chińsko-amerykańskie $w$ warunkach rozwoju nowoczesnych technologii. Wydawnictwo Adam Marszałek.

Marszałek-Kawa, J., \& Dmochowski, T. (Eds.). (2021). Selected Socio-Economic and International Relations Issues in Contemporary Asian States. Wydawnictwo Adam Marszałek.

Marszałek-Kawa, J., \& Stelmach, A. (Eds.) (2021). Dynamika procesów politycznych i społecznych w państwach południowej i wschodniej Azji. Wydawnictwo Adam Marszałek.

Ministry of Foreign Affairs of Japan. (2017). Diplomatic Bluebook 2017.https://www.mofa.go.jp/policy/ other/bluebook/2017/html/chapter1/c0102.html\#sf03

Mohan, C.R., \& Vater, J. (2021). Biden and South Asia. In C.R. Mohan, \& J. Vater (Eds.), President Biden and South Asia (pp. 3-12). National University of Singapore.

Palmer, J. (2021). Another Win for China's Hostage Diplomacy: A yearslong diplomatic dispute between China and the West has finally ended. Foreign Policy. https://foreignpolicy.com/2021/09/28/mengwanzhou-michael-kovrig-spavor-release-china-canada-huawei/

Seah, S., Hoang Thi, H., Martinus, M., \& Pham Thi Phuong, T. (2021). The State of Southeast Asia 2021: Survey Report. ASEAN Studies Centre.

The Department of Defense. (2019). Indo-Pacific Strategy Report: Preparedness, Partnerships, and Promoting a Networked Region. https://media.defense.gov/2019/Jul/01/2002152311/-1/-1/1/ DEPARTMENT-OF-DEFENSE-INDO-PACIFIC-STRATEGY-REPORT-2019.PDF

The White House. (2015). National Security Strategy of the United States of America 2015. https:// obamawhitehouse.archives.gov/sites/default/files/docs/2015_national_security_strategy_2.pdf

The White House. (2017). National Security Strategy of the United States of America 2017. https:// www.whitehouse.gov/wp-content/uploads/2017/12/NSS-Final-12-18-2017-0905.pdf

The White House. (2021). Interim National Security Strategic Guidance. https://www.whitehouse.gov/ wp-content/uploads/2021/03/NSC-1v2.pdf

The White House. (2021). Remarks by President Biden, Prime Minister Morrison of Australia, and Prime Minister Johnson of the United Kingdom Announcing the Creation of AUKUS. https://www. whitehouse.gov/briefing-room/speeches-remarks/2021/09/15/remarks-by-president-biden-primeminister-morrison-of-australia-and-prime-minister-johnson-of-the-united-kingdom-announcingthe-creation-of-aukus/ 